\title{
非水溶液中のマグネシウム酸化挙動
}

\author{
柴田 正実*, 大森 大輔, 古屋 長一

\section{Electrochemical Behavior of Magnesium Anode in Non-aqueous Solutions}

\author{
Masami SHIBATA*, Daisuke OMORI and Nagakazu FURUYA
}

Received August 20, 1997 ; Accepted January 9, 1998

\begin{abstract}
Electrochemical behavior of magnesium anode was investigated in THF-DMF mixture with $0.5 \mathrm{M}$ tetra $\mathrm{n}$-butylammonium bromide. The potential of $\mathrm{Mg}$ anode at oxidation currents less than $5 \mathrm{~mA} \mathrm{~cm} \cdot 2$ remained stable for at least $60 \mathrm{~min}$ in the electrolyte with $<0.1 \%$ water. Magnesium metals were oxidized to $\mathrm{Mg}^{2+}$ ions in the electrolyte containing < $0.1 \%$ water, where magnesium oxides are hardly formed on the anode surface. On the other hand, the potential of $\mathrm{Mg}$ anode rose with time in the electrolyte with $1 \%$ water. The surface of $\mathrm{Mg}$ anode was covered with $\mathrm{Mg}$ oxides or hydroxides having micro pores in the electrolyte with $1 \%$ water.
\end{abstract}

\section{1 緒 言}

水溶液系の電解臬元の場合には，対極のアノード反応 として, 通常, 酸素発生反応が進行する. 有機電解液中 では，有機溶媒あるいは電解質の酸化分解が起こる．非 水溶液に用いられる有機溶媒および電解質は高価であり， またこれらが酸化した物質は電極反応を阻害するので， 電解液の酸化消耗を極力避けなければならない。

容易に酸化される物望が存在すれば，有機溶媒および 電解質の酸化分解を回避することができる．標準電極電 位が低い金属をアノードとして用いると，電極自身が酸 化し，金属イオンとなって非水溶液中に溶解しながら消 耗していく.このような反応性電極 1)(あるいは犠牲電極 とも呼ばれる)の電極材料として $\mathrm{Mg}, \mathrm{Al}, \mathrm{Zn}$ 金属などが ある 1.4). 有機電解合成では, 反応性電極の溶解は単に電 解液の分解を避けるためばかりではなく，生成した金属 イオンが反応中間体を補足して安定化させる効果がある. これにより，目的とする還元反応が高効率で起こると考 えられている ${ }^{1-4)}$. 反応性電極として適する金属の種類は 各々の反応で異なる．種々の反応に対して最適な電極が スクリーニングされてきた 1.4). しかし，アノード消耗に よる金属イオンの生成が重要であるにもかかわらず，反 応性電極の酸化溶解過程については十分に明らかにされ てはいないままた，カソード反応に対する水分の影䈉に ついては種々検討されているが, 反応性電極の溶解反応 に対する水分の影響については殆ど検討されていない．

本研究では, $\mathrm{Mg}$ 電極の酸化溶解举動と表面状热につい て調へ，また，系中の水分の影響について明らかにする

山梨大学工学部 (广400-8511 甲府市武田 4-3-11)

Faculty of Engineering, Yamanashi University (4-3-11 Takeda, Kofu 400-8511 Japan)

Key Words: $\mathrm{Mg}$ anode, Reactive-metal anode, $\mathrm{Mg}$ surface, non-aqueous solutions.
ことを目的とした

\section{2 実笶方法}

\section{1 策解液}

テトラヒドロフラン（以後 THF と略す，関東化学，特 級 $>99.7 \%$ ) と N,N-ジメチルホルムアミド（以後 DMF と略す. 関東化学, 特級 >99.7\%) を 1:1 の割合で混合し た溶液に支持電解貿として $0.5 \mathrm{M}$ 臭化テトラブチルアン モニウム（ナカライテスク，特級）を溶解して電解液と した. モレキュラーシーブを適当量加え脱水した。これ に任意の水を加えて, 含水量 $0.1,0.2,0.25,1.0 \%$ の電解 液を調整した．含水量はガスクロマトグラフィーで定量 した.

\section{2 掼极，解セル，装置}

純度 $99.95 \%$, 直径 $1.6 \mathrm{~cm}$ の $\mathrm{Mg}$ 楱を厚さ $0.5 \mathrm{~cm}$ にス ライスし, ディスク状に加エした. 表面を 2000 番のエメ リーで磨いた後, 硝酸エッチングし 5), 電極とした。作 用面は直径 $1 \mathrm{~cm}$, 表面積 $0.79 \mathrm{~cm}^{2}$ とした. カソードは ステンレス䈃（SUS304）を使用し, 表面積 $1.54 \mathrm{~cm}^{2}$ と した. 参照電極として $\mathrm{Ag} / \mathrm{Ag}^{+}\left(\mathrm{Ag}\right.$ 線 $\left.\left./ 0.01 \mathrm{M} \mathrm{AgClO}_{4}\right){ }^{6}\right)$ を使用し，測定ことに調整し直した。

室温で定電流電解行い，電位を測定した。なお，電 位液抵抗補正を行った.電解後には, $\mathrm{Mg}$ アノードの重 量変化測定および走査型電子顕微鏡（以後 SEM と略す。 日本電子, JSM-5310LV) による表面観察, 電子線プロ 一プイクロアナライザー（以後 EPMA と略す. 日本電 子, JXA-8600S/M) とエネルギー分散型 X 線分析装置 (堀 場製作所 S-4500，EMAX-5770）による元素同定および 面分析, X 線光電子分光装置 (以後 XPS と略す. 島津製 作所，ESCA-750S）による状態分析を行った。

\section{3 的解液中の $\mathrm{Mg}$ の定量}

電解後の電解液中の $\mathrm{Mg}$ 総量 $(\mathrm{Mg}$ を含む微小固形物と $\mathrm{Mg}$ イオン量の総量) 忺次のように定量した. 電解液 0.11 $\mathrm{ml}$ を採り蒸発乾固後, 残分を $0.05 \mathrm{M}$ 塩酸 $1 \mathrm{ml}$ で溶解 
した. $\mathrm{pH}$ を調整した後,この溶液をエリオクロムフララッ ク T法により発色し，吸光光度計で分析した．また，電 解液中の $\mathrm{Mg}$ イオン濃度は孔径 $200 \mathrm{~nm}$ のテフロンフィル ターで電解液をろ過し固形分を分雄した後，ろ液を上記 の方法で定量した。固形分は，フーリエ変換赤外分光光 度計（以後 FT-IR と略す．島津製作所，FT-IR 8100）を 用い，拡散反射法（島津製作所，DR-8000）でマグネシ ウム化合物の定性を行った。

\section{3 結果およひ考察}

\section{$3.1 \mathrm{Mg}$ アノード位に及ほす含水畠の影蓄}

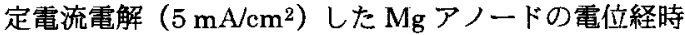
変化を Fig.1 に示す. 含水量 $0.1 \%$ 1\%の電解液中の結 果である.電解初期の $\mathrm{Mg}$ 電極電位は含水量 $0.2 \%$ 以下で は低下するが,含水量 $0.25 \%$ 以上で上昇する傾向にある. 含水量 $0.1 \%$ 電解液での $\mathrm{Mg}$ 電極電位は初期に低下し た後，わずかに上昇して，以後安定である，一方，含水 量 $1 \%$ の電解液では電位が初期に上昇した後, 電位振動 し始め，約 30 分後から急激に上昇する。これは後に述べ るように $\mathrm{Mg}$ 酸化皮膜の生成によるものである.含水量 $0.1 \%$ 電解液中では，含水量 $1 \%$ に比へ $\mathrm{Mg}$ が容易に酸 化することがわかった。

$$
Q / \mathrm{C} \mathrm{cm}^{-2}
$$

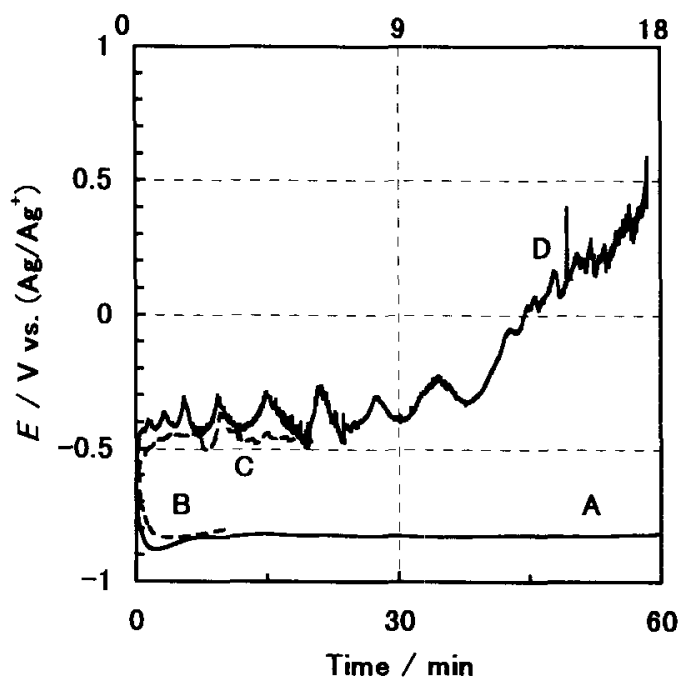

Fig. 1 Relation between the potentials of $\mathrm{Mg}$ anode in the electrolyte containing water and the electrolysis time. (A) $0.1 \%$, (B) $0.2 \%$, (C) $0.25 \%$, (D) $1 \%$.

\section{$3.2 \mathrm{Mg}$ の酸化溶解価数}

$\mathrm{Mg}$ 電極を酸化溶解したときの電極消耗量,電解液中の $\mathrm{Mg}$ 量の経時変化を含水量 $0.1 \%$ 電解液中で調へ, Fig.2に示した. 電解後の電解液は逶明であり, 電解液中 に固形物は目視できなかった．電解液中の $\mathrm{Mg}$ 総量 (O) は電極消耗量 ( $\boldsymbol{\Delta}$ :電解前後の電極重量変化加ら求妨た消 耗モル数) とよく一致した. Mg が 2 価で酸化溶解すると
仮定してファラテーの法則から算出した理論量を実線で 示す．電解液中の $\mathrm{Mg}$ 総量は，この理論量から大きくず れている。そこで, 電解液を $200 \mathrm{~nm}$ のテフロンフィル ターを用いてろ過し，ろ液中の $\mathrm{Mg}$ イオン量 (৩) を調 ベた. $\mathrm{Mg}$ イオン量と理論量はよく一致することから， $\mathrm{Mg}$ アノードは 2 価で酸化溶解することがわかった.また， 電極消耗量の一部 (1/3 程度) は微小な $\mathrm{Mg}$ 固形物 $(200$ $\sim 1000 \mathrm{~nm}$ 程度の大きさ）として電極から脱落するもの

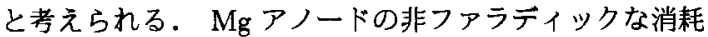
は水溶腹系でも報告されている7，酸性水溶液中では， 次のような反応機構が提案されている7).

$$
\mathrm{Mg}+2 \mathrm{HA} \rightarrow \mathrm{H}_{2}+\mathrm{MgA}_{2}
$$

ここで，Aはアニオンである. $\mathrm{Mg}$ は酸と反応し，マグネ シウム塩を生成して電極から脱離する．水分を多く含ん だ非水溶腹中のアノード反応では酸素発生が併発する。 これに伴って電極近傍には $\mathrm{H}^{+}$が生ずるので，反応式(1) に類似した反応が起こることも考えられる。しかし，含 水量 $0.1 \%$ の非水溶液中における $\mathrm{Mg}$ 脱落過程は，この反 応機構からは説明できない。この $\mathrm{Mg}$ 脱落過程に関する 考察は後述 (3.3 Fig. 7 参照) する. 電解後の電極表面 は金属光沢があり，また電解液の着色等の変化はなかっ た.ファラデーの法則に Mg イオン量が一致することか らも，電解腹あるいは電解質自身の酸化が起こっていな いことがわかった。

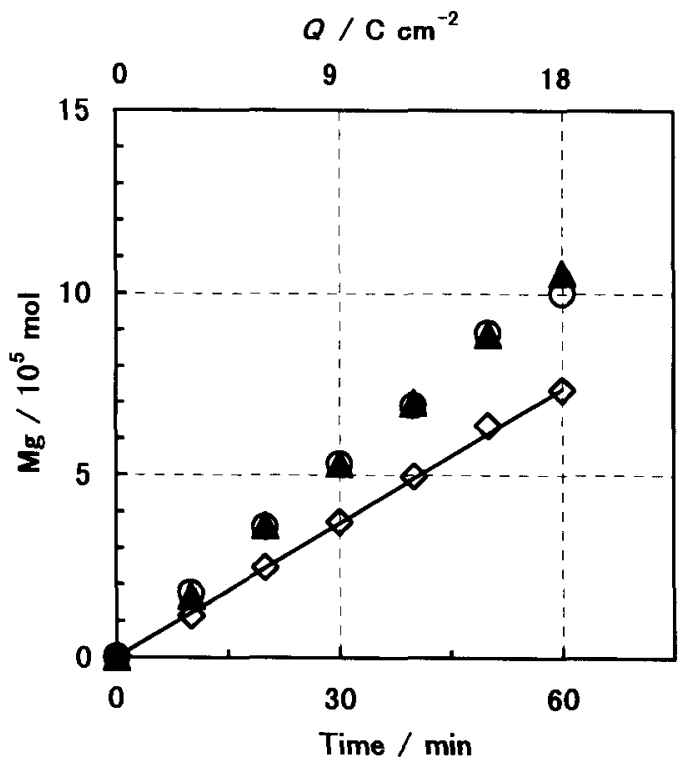

Fig. 2 Correlation between the weight loss of $\mathrm{Mg}$ anode and the amount of $\mathrm{Mg}$ in the electrolyte containing $0.1 \%$ water and the electrolysis time at $5.0 \mathrm{~mA} / \mathrm{cm}^{2}$. $\Delta$ : the weight loss of $\mathrm{Mg}$ anode, $\mathrm{O}$ : the total amount of $\mathrm{Mg}$ in the electrolyte, $\diamond:$ the amount of $\mathrm{Mg}^{2+}$ ions, - : Faraday's low.

含水量 $1 \%$ 電解液中において, $\mathrm{Mg}$ 電極を $5 \mathrm{~mA} \mathrm{~cm}^{2}$ で酸化すると，電極表面は灰色のポーラスな厚い皮膜と 
粘着物で覆われた。これが剥がれ落ちてセルの底に堆䅡 しているのが観察できた。また, 電解中にカソードから 水素が発生した．所定時間電解後，超音波洗浄で電極上 の剥がれそうな部分を電解液中に落とした後, 電解液の 分析を行った.電解液中の Mg 量の経時変化を Fig.3に示 す。電解液中の $\mathrm{Mg}$ モル総量 (O) は電気量の増加と共 に值線的に增加することがわかった. 電解液中の $\mathrm{Mg}$ イ オン量（○）は電解初期には電気量と共に増加するが, 電解 30 分以後では增加しない. 30 分以後では $\mathrm{Mg}$ イオ ンが生成せず，灰色の固形物のみが生成することがわか った.

$$
Q / \mathrm{C} \mathrm{cm}^{-2}
$$

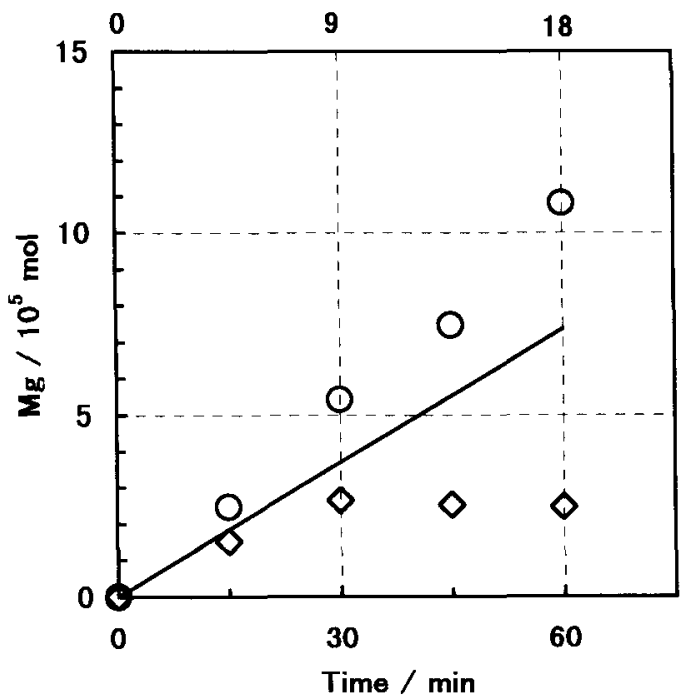

Fig. 3 Correlation between the amount of $\mathrm{Mg}$ compound and $\mathrm{Mg}^{2+}$ ions in the electrolyte containing $1 \%$ water and the electrolysis time at $5.0 \mathrm{~mA} / \mathrm{cm}^{2}$. $O$ : the total amount of $\mathrm{Mg}$ in the electrolyte, $\diamond:$ the amount of $\mathrm{Mg}^{2+}$ ions, - : Faraday's low.

電解 30 分以後, $\mathrm{Mg}$ イオンが生成しない現象が電解液 に基因するものか，あるいは電極に因るものかを明確に するために，以下の実験を行った. 電解 45 分後の電解液 (৩) を用い, 新しい $\mathrm{Mg}$ 電極に付け替えて再び電解を 行った結果を Fig.4に示す. 再度電解した電解液中の $\mathrm{Mg}$ イオン量(○)は,さらに增加し $4 \times 10^{-5} \mathrm{~mol}$ 程度になるが, 電解 30 分以後增加しない. 新しい $\mathrm{Mg}$ 電極は初期には $\mathrm{Mg}$ イオンとして酸化溶解することがわかった. 電解 30 分以後では, 電極表面は灰色のポーラスな皮膜で覆われ ていた。すなわち， $\mathrm{Mg}$ イオンの生成は電解液中の $\mathrm{Mg}$ イオン量の飽和によって抑制されるのではなく, 電解に よって生じたアノード皮膜によって抑制されることがわ かった.

電解中に $\mathrm{Mg}$ 電極表面から剥がれ落ちた灰色の沈殿物 を $\mathrm{THF}$ 溶液で十分洗浄し乾燥すると白色の粉末となっ
た.これを拡散反射法によるFT-IRで測定した。その結 果を Fig.5 に示す. 図中 D が末知の白色粉末のスペクト ルである. A, B, Cはおのおの $\mathrm{Mg}, \mathrm{MgO}, \mathrm{Mg}(\mathrm{OH})_{2}$ の

$$
Q / \mathrm{C} \mathrm{cm}^{-2}
$$

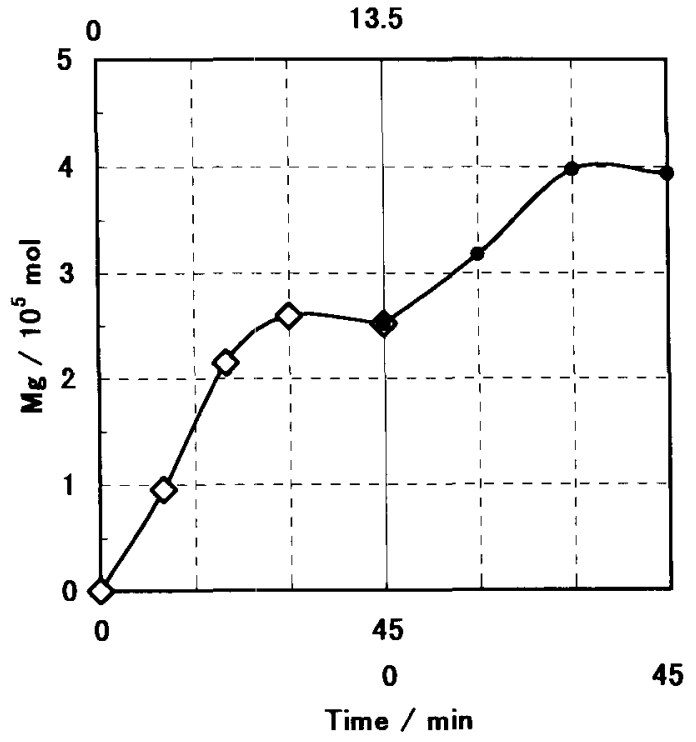

Fig. 4 Correlation between the amount of $\mathrm{Mg}^{2+}$ ions in the electrolyte containing $1 \%$ water and the electrolysis time.

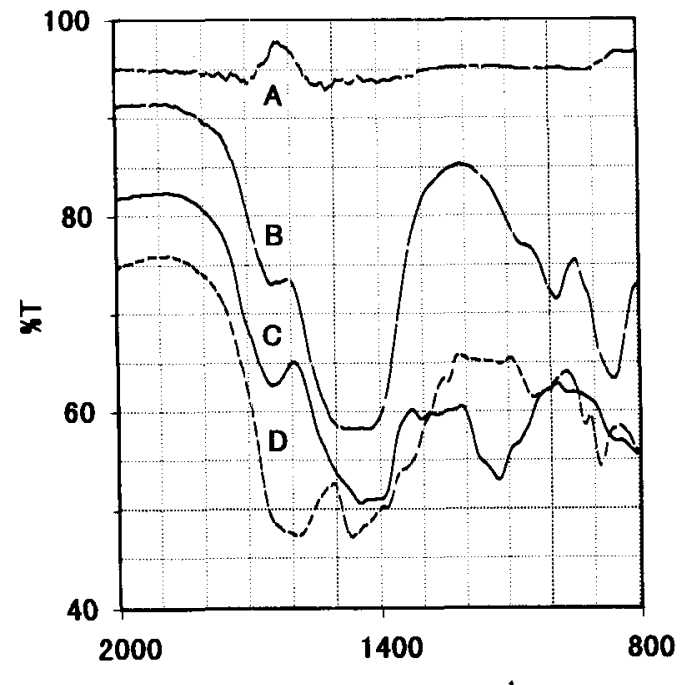

Wavenumber $/ \mathrm{cm}^{-1}$

Fig. 5 FTIR reflection spectra of (A) Mg metal, (B) $\mathrm{MgO}$, (C) $\mathrm{Mg}(\mathrm{OH})_{2}$ and (D) pow der obtained after electrolysis in the electrolyte with $1 \%$ water. 
標準試料である. Dの $1500 〜 1400 \mathrm{~cm}^{-1}$ および, $1650 \mathrm{~cm}^{-1}$ 付近の吸収か $\mathrm{MgO}, \mathrm{Mg}(\mathrm{OH})_{2}$ の吸収に類似することか ら, Mg 電極表面から剥がれ落ちた白色固体は $\mathrm{Mg}$ 酸化物 あるいは水酸化物であると考えられる.なお $1400 \mathrm{~cm}^{1}$ 付 近よりも低波数領域にはパラフィン類，オレフィン類に 帰属される吸収がある. 白色粉末表面には，電解液の分 解生成物（3.3 と 3.4 参照）加 THF 溶液洗浄後も微量付 着している。このため, D の FT-IR スペクトルは B， C のスペクトルとは，完全には一致しないものと考えられ る。

\section{$3.3 \mathrm{Mg}$ 霜極の表分析}

含水量 $0.1 \%$ 電解液中, $\mathrm{Mg}$ 電極を $5 \mathrm{~mA} / \mathrm{cm}^{2}$ で酸化 溶解したときのSEM 像の一部を Fig.6に示す.電解前の $\mathrm{Mg}$ 電極表面は平滑であり,コントラストを付けて観察す ると Fig.6 a のように結晶粒が確認できた。Fig.6 b に示 したように電解直後, 表面には酸化溶解による無数の微 小な孔が生じた. $\mathrm{Mg}$ 金属が $\mathrm{Mg}$ イオンとして酸化溶解し たものと考えられる。この微小な孔生成は, 結晶面お よび粒界等には依存しない，この孔が生成するきっかけ は，恐らく $\mathrm{Mg}$ 金属中の不純物（あるいは格子久陥）に よるものと考えられる．微小な孔は $\mathrm{Mg}$ 溶出とともに広 がり，互いにつながり大きくなっていく過程が Fig. 6 b 中 で見られる.さらに, Fig.6 c とdに示したように電解か 進むにつれて山みが大きく広がっていくことがわかった。 Fig.6 dでは, 凹みの底に, さらに微小な孔が生成し，こ れが大きく成長してきた様子がうかがえる。酸化溶解部 分の形状変化を調べるために, 電解 5 分後と 15 分後の電 極の断面を SEM 観祭した. その結果, Mg 酸化溶解は深 さ方向に進むより，むしろ，約 $0.005 \mathrm{~mm}$ の深さで二次元 的に酸化溶解していることがわかった．山みの底に，さ らに成長した孔の深さも約 $0.005 \mathrm{~mm}$ であった。しかしな がら，約 $0.005 \mathrm{~mm}$ の深さで山み（または孔）が成長する
理由に関しては不明である. $\mathrm{Mg}$ 電極表面の元素分析と 面分析をした結果, 電解前後で表面の酸素強度はほとん ど変化していないことがかかったＸPSで電極表面の状 態分析を行った結果， $\mathrm{Mg} 2 \mathrm{~s}$ 結合エネルギーのピークは

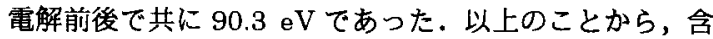
水量 $0.1 \%$ 電解液中では, $\mathrm{Mg}$ は酸素化合物を形成せず に, $\mathrm{Mg}$ イオンとして酸化溶解することが分かった.

$\mathrm{Mg}$ 溶解過程を模式的な図で描くと, Fig. 7のようにな る. Fig. 7Aのaで示したような微小な孔か広がり, Fig. $7 \mathrm{~B}$ の b のようになる. Mg 酸化溶解が深さ方向に進行せ ず, 二次元的に進むことを考虑すると, $\mathrm{Mg}$ 溶解は活性点 と考えられる凹み（または孔）の淵（Fig.7B中の m で 示した）から起こり，凹み（または孔）の底に達して止 まる。これを繰り返して，凹み（または孔）が広がって いくと考えることができる，広がった凹みの底には，Fig， 7C中の $\mathrm{c}, \mathrm{d}$ で示したような新たな微小な孔が生ずる.こ の微小孔の生成も，前述したように，恐らく $\mathrm{Mg}$ 金属中 の不純物（あるいは格子久俢）がきっかけとなって生成 するものである.凹みが広がっていく過程で，Fig. 7C 中 の e, f, Fig. 7D中のi, jあるいは Fig. 7E 中のlに示し たような $\mathrm{Mg}$ 金属の突起が生ずる.この突起下部に不純 物（あるいは格子久陥）か存在する場合には，微小孔か 生成する過程と同梯に，この部分の $\mathrm{Mg}$ 加容易に溶解し， 上部の $\mathrm{Mg}$ が表面から脱落するもの（Fig. 2 およびその 結果を参照）と考えることができる．不純物（あるいは 格子欠陌など）のところで金属が溶解しやすいと通常考 えられているが, 本報では今のところその実騟的根拠に 乏しい，従って，上記で提案した $\mathrm{Mg}$ 酸化溶解機構につ いては，さらに詳細な検討が必要である.

一方, 含水量 $1 \%$ の電解液で $\mathrm{Mg}$ 電極を酸化溶解したと きの SEM 像を Fig. 8 に示す. 電解直後 (Fig. 8 a) では, Fig.6 a に比へて細かく深い穴が見られた. 電解 5 分後で

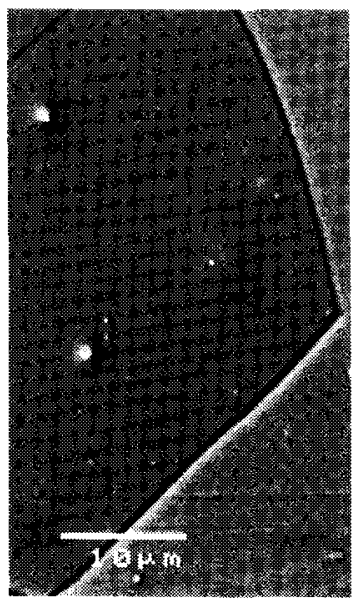

a

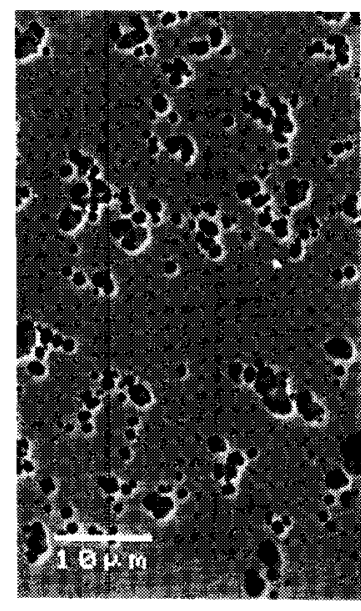

b

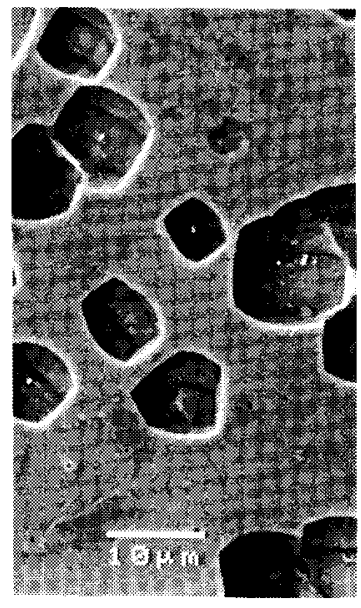

c

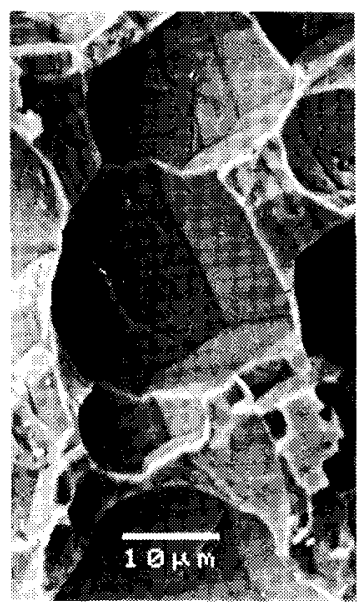

d

Fig. 6 SEM photograph of surface of $\mathrm{Mg}$ anode after electrolysis in the electrolyte with $0.1 \%$ water. (a) $0 \mathrm{sec}$, (b) $5 \mathrm{sec}$, (c) $5 \mathrm{~min}$, (d) $30 \mathrm{~min}$. 


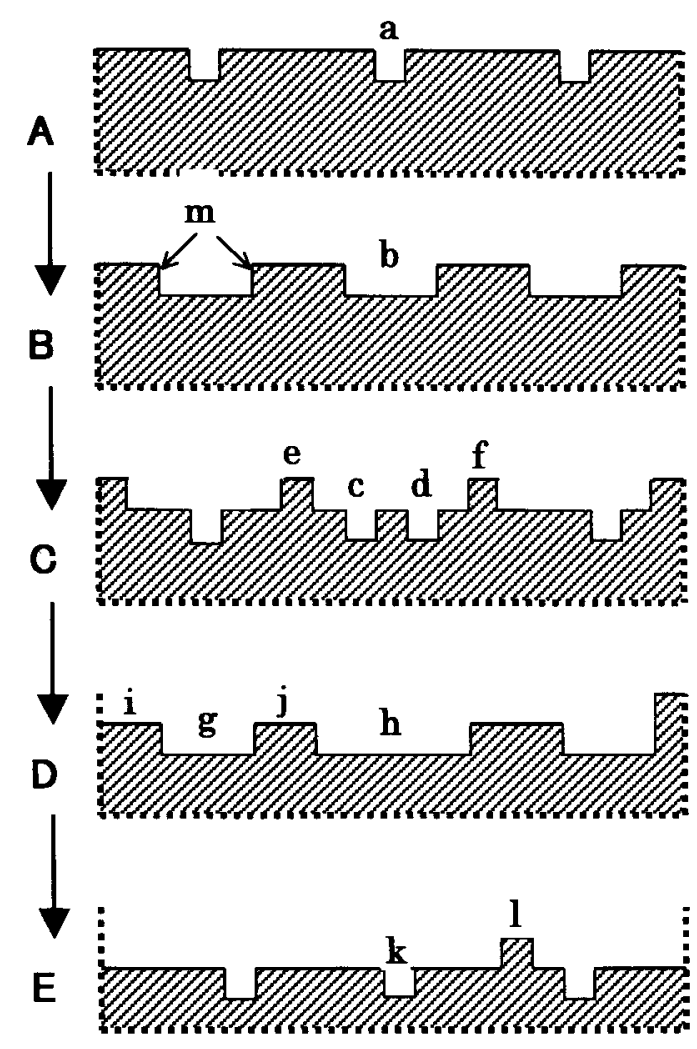

Fig. 7 Schematic cross sections of $\mathrm{Mg}$ anode.
は、これが表面全体に広がり，微細孔をもつ層を形成し ているのか観察された。電解 30 および 60 分後には，こ の微細孔をもつ層はさらに厚くなり，大きな亀裂と剥が れ落ちている筒所もみられた。電解 60 分後の電極表面を 元素同定および面分析した. EMAX 检出器による酸素元 素のカウント数は電解前に比べて数十倍になることがわ かった．面分析から，表面全体に酸化皮膜が生成してい ることが分かった.XPSで電極表面の状態分析を行った 結果, $\mathrm{Mg} 2 \mathrm{~s}$ 結合エネルギーのビーク $(90.3 \mathrm{eV})$ は電解 後に $0.3 \mathrm{eV}$ ほど高エネルギ一側にシフトすることが分か った。電解で $\mathrm{Mg}$ 表面は酸化され， $\mathrm{MgO}$ もくは $\mathrm{Mg}(\mathrm{OH})_{2}$ が生成したものと考えられる。この結果は FTIR の分析結果（Fig.5 参照）と一致する.含水量 $1 \%$ の電 解液では，電解にともない，微細な空孔をもつ $\mathrm{Mg}$ 酸化 物あるいは水酸化物層が成長し，これによって，過電压 か上昇（Fig. 1 およでFig. 10 参照）することがわかった. EMAX 検出器を用いて面分析した結果, 電解後の $\mathrm{Mg}$ 酸 化物あるいは水酸化物層から臭素も検出された。これは 過電圧の上昇によって電解質が一部酸化分解したことを 示唆するものである.

Nordlien ら 8)は加湿空気および水中に曝された $\mathrm{Mg} の$ 断面を詳細に TEM 観察し, 酸化皮膜構造を解析した。 酸化皮膜は $\mathrm{MgO}, \mathrm{Mg}(\mathrm{OH})_{2}$ および水和物からなる platelet 層 $(400 \sim 600 \mathrm{~nm})^{8)}$, 密な層 $(20 \sim 40 \mathrm{~nm})$, cellular 層 $(1800 \sim 2200 \mathrm{~nm})^{8)}$ の三層構造からなることを明らか にした.Fig. $8 \mathrm{~d}$ の皮膜の裂け目には platelet 層に類似し た多孔質の組織がみられる。しかし，この酸化皮膜の厚 さは 1〜2mm 程度もあり, Nordlien らが調べた皮膜とは 尺度が大きく異なる、今後，Fig. 8 で示したような $\mathrm{Mg}$ 酸化皮膜を断面観察し，その皮膜構造を明らかにした上 で, 酸化皮膜生成機構を検討しなければならない。

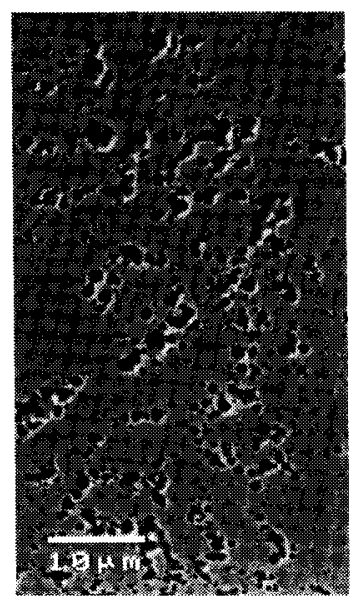

$\mathbf{a}$

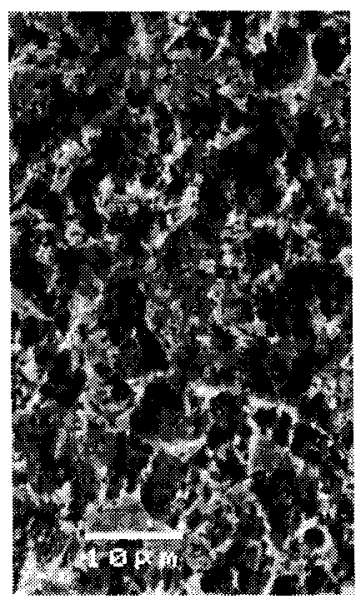

b

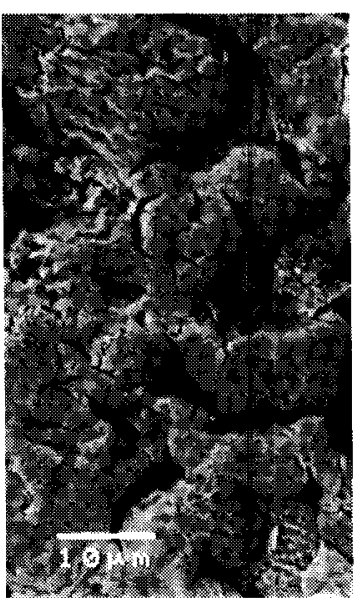

c

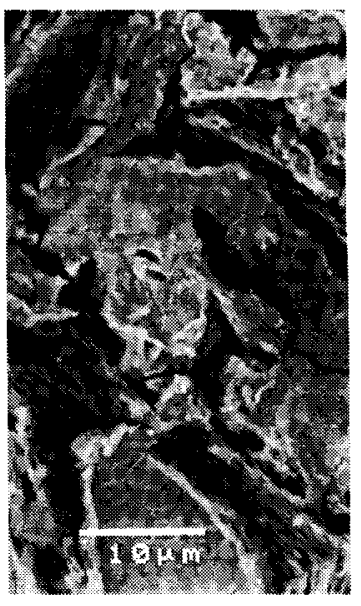

d

Fig. 8 SEM photograph of surface of $\mathrm{Mg}$ anode after electrolysis in the electrolyte with $1 \%$ water. (a) $5 \mathrm{sec}$, (b) $5 \mathrm{~min}$, (c) $30 \mathrm{~min}$, (d) $60 \mathrm{~min}$. 


\section{4 酸化筑流密度の影}

含水量 $0.1 \%$ 電解液中で調ベたアノード電位の経時変化 を Fig. 9 に示す. 電流密度 $2.5 \sim 10 \mathrm{~mA} / \mathrm{cm}^{2}$ ではいずれも 電位の急激な変化はないことがわかった. 電解後の電極 表面はいずれの場合も金属光沢があり，電解液の変化は

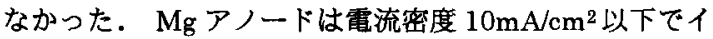
オンとして容易に酸化溶解することかかかった。電流密 度 $15 \mathrm{~mA} / \mathrm{cm}^{2}$ ではアノード電位の上昇が観察された。電 解後の電極表面は金属光沢があったが，粘着物質が表面 に付着していたこの粘着物質によって $\mathrm{Mg}$ 溶解が妨げ られ，電位が急上昇したものと考えられる。この粘着物 質は電解液の酸化生成物と考えられるが，この物質の同

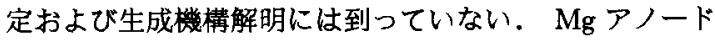
を反応性電極として使用する場合には，電流密度 $10 \mathrm{~mA} / \mathrm{cm}^{2}$ 以下とするのがよいことが分かった。

含水量 $1 \%$ の電解液でのアノード電位の経時変化を Fig. 10 に示す. 電流密度 $2.5 \sim 10 \mathrm{~mA} / \mathrm{cm}^{2}$ ではいずれも 電極表面に灰色の非常にもろい物質が生成し，これが剥

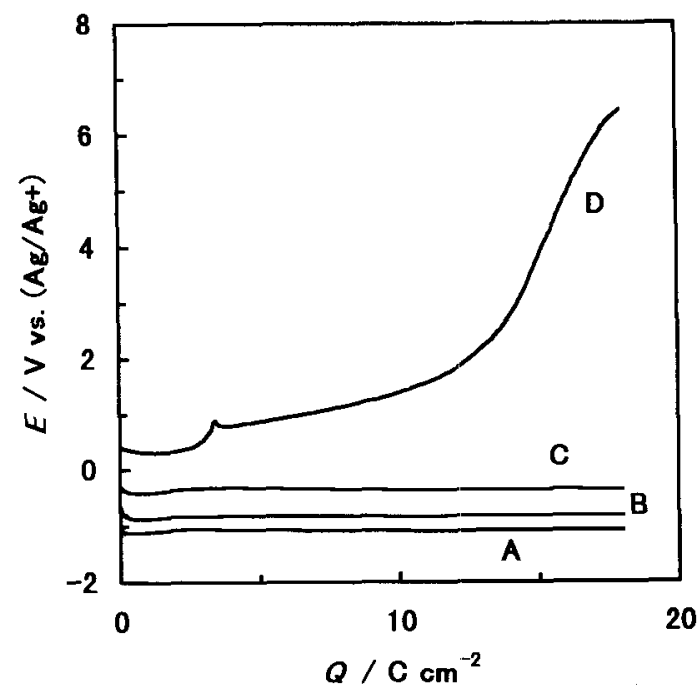

Fig. 9 Relation between the potentials of $\mathrm{Mg}$ anode in the electrolyte with $0.1 \%$ water and the electrolysis time. (A) $2.5 \mathrm{mAcm}^{-2}$, (B) $5 \mathrm{mAcm}^{2}$, (C) $10 \mathrm{mAcm}^{-2}$, (D) $15 \mathrm{mAcm}^{-2}$.
がれ落ちてセル底に沈降していた，電流密度 5 と $10 \mathrm{~mA} / \mathrm{cm}^{2}$ では 10 クーロン通電以後, 電位が著しく上昇 することかわかった。

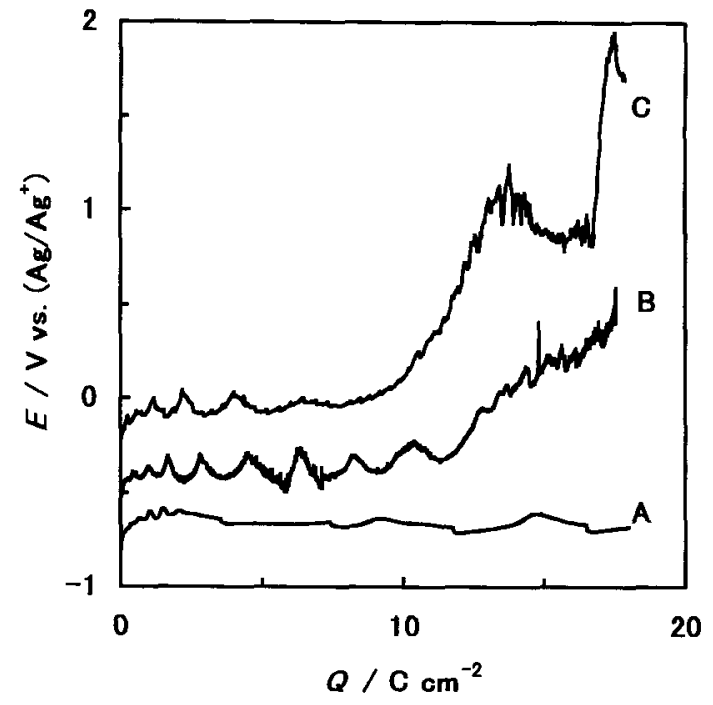

Fig. 10 Relation between the potentials of $\mathrm{Mg}$ anode in the electrolyte with $1 \%$ water and the electrolysis time. (A) $2.5 \mathrm{mAcm}^{-2}$, (B) $5 \mathrm{mAcm}^{2}$, (C) $10 \mathrm{mAcm}^{-2}$

\section{文 献}

1) 徳田昌生, 電気化学, 65,614 (1997)

2) J. Chaussard, J.-C. Folest, J.-Y. Nedelec, J. Perichon, S. Sibill and M. Troupel, Synthesis, 5, 369 (1990).

3) J. M. Paratian, E. Labbe, S. Sibille, J.-Y. Nedelec and J. Perichon, Denki Kagaku, 62, 1129 (1994).

4) G.Silvestri, S. Gambino, G. Filardo, G. Spadaro and L. Palmisano, Electrochim. Acta, 23, 413 (1978).

5) G. Petzow，金属エッチング技術アグネ社 (1977).

6) 伊豆津公祐, 非水溶媒 電気化学, 培風館, (1995).

7) P. F. King, J. Electrochem. Soc., 113, 536 (1966).

8) J.H. Nordlien, S. Ono, N. Masuko and K. Nisancioglu, J. Electrochem. Soc., 142, 3320 (1995). 